Journal of Educational Research in Developing Areas (JEREDA)

Vol. 2. Issue 2, Pp. 196-207, 2021

http://www.jeredajournal.com

E-mail: info@jeredajournal.com

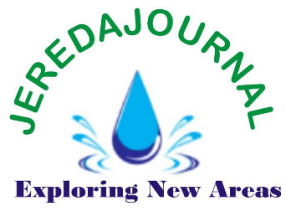

Mini-Review DOI:https://doi.org/10.47434/JEREDA. eISSN:2735-9107

\title{
EMPIRICAL REVIEWS OF CAREER PLATEAUING AND TURNOVER INTENTIONS OF TEACHERS' EXPERIENCE TO PURSUE FURTHER STUDIES IN KENYA
}

\author{
${ }^{1}$ Mary Gaturu, ${ }^{2}$ Felicita Wanjiru Njuguna, \\ ${ }^{3}$ Rufus Olanrewaju Adebisi
}

${ }^{1}$ National Office, Assurance and Standards, Ministry of Education, Kenya

${ }^{2}$ Education Management Policy and Curriculum Studies, Kenyatta University, Kenya.

${ }^{3}$ Federal College of Education (Special), Oyo, Nigeria

Email: ${ }^{1}$ wanjisjnu@gmail.com; ${ }^{2}$ marygaturu@yahoo.com; ${ }^{3}$ aderufus2@gmail.com

Corresponding Author: ${ }^{1}$ wanjisjnu@gmail.com

(Di) https://orcid.org/0000-0002-7062-7816

Received: $09^{\text {th }}$ November, 2020; Revised: $30^{\text {th }}$ March, 2021; Accepted: $18^{\text {th }}$ September, 2021

\begin{abstract}
PURPOSE: The purpose of this paper was to review the various studies on the relationship between career plateauing, turnover intentions and teacher decisions in order to pursue further studies.

METHODS: The empirical study focused on the forms of career plateauing faced by teachers, the relationship between career plateauing and turnover intentions, the relationship between turnover intentions and teacher preparation, the history characteristics of career plateauing and turnover, and techniques to enrich the quality of teacher work to fight career plateauing. Two forms of career stagnation were described in the review: structural (hierarchical) plateauing and content (job content) plateauing.

RESULTS: The analysis of the studies has shown that previous researchers have studied the influence of career plateauing on organizational variables such as turnover intentions, work satisfaction and organizational engagement. Previous studies have shown that work plateauing has been negatively associated with job satisfaction and organizational engagement and positively correlated with turnover intentions. The reviewed literature also found that there are a variety of techniques that can be used to improve the job content of teachers to address the career plateau.

CONCLUSION AND RECOMMENDATIONS: The review tried to define the type of plateauing that Kenyan teachers often face. While the reviews have shown that career plateauing is becoming increasingly widespread in various organizations, there has been little research in Kenya especially among secondary school teachers. The study therefore recommended that studies be undertaken to determine the relationship between career graduation, turnover intentions and the decision of the instructor to undertake post-graduate studies in Kenya.
\end{abstract}

Keywords: Career plateauing, turnover intentions, job content, further studies.

Cite paper as:

Crossref Gaturu, M., Njuguna, F. W., Adebisi, R. O. (2021). Empirical reviews of Cited-by career plateauing and turnover intentions of teachers' experience to pursue further studies in Kenya. Journal of Educational Research in Developing Areas, 2(2), 196-207. https://doi.org/10.47434/JEREDA.2.2.2021.196.

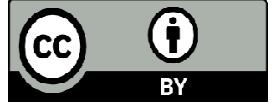

Copyright (c) 2021 The author(s) of this article retain(s) the copyright. 
Journal of Educational Research in Developing Areas (JEREDA)

Vol. 2. Issue 2, Pp. 196-207, 2021

http://www.jeredajournal.com

E-mail: info@jeredajournal.com

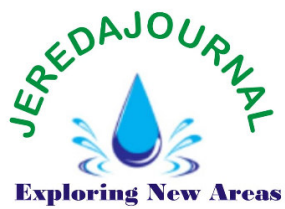

\section{PUBLIC INTEREST STATEMENT}

This review is significant in that the authors wished to establish whether there was a relationship between plateauing and taking up more courses. This review was expected to inform the stakeholders of the situation as one of the resaons why they were loosing many teachers and therefore the perenial shortage of teachers.

\section{INTRODUCTION}

Career Stagnation refers to the condition in one's career where there is very little chance of additional hierarchical advancement (Ongori \& Angolla, 2009). In other words, career plateauing occurs when a person has achieved the highest position that he or she can possibly achieve within an organization and has no prospect of being promoted in the future. Career Plateauing is a term that refers to a sense of discontent encountered by employees in an organization when career development prospects are no longer available (Choudhary, Ramzan \& Riaz, 2013; Rotondo \& Perrewe, 2000). It was established as one of the characteristics of the teaching profession (Atteberry, Loeb \& Wyckoff, 2013).

As teachers encounter career paths, they can register intentions to leave the teaching profession for other careers or what is referred to as turnover intentions. Turnover intention can be characterized as employees who are perceived to be likely to remain or leave an organization (Cotton \& Tuttle, 1986). These two factors - job grading and turnover intentions - can have a detrimental effect on the standard of teaching in our schools. From Bardwick (1986), two types of career plateau are observed: plateau work content and hierarchical (or structural) plateau. Job material plateau is the product of the general staleness of the job itself. Employees believe like they are not challenged by the work and duties they carry out on a regular basis. On the other hand, the bureaucratic (or structural) plateau emerges as a result of workers having little or no chance of further advancing the company (Bardwick, 1986). A further categorization of career plateauing is offered by Burke and Mikkelsen (2006), who claim that in addition to systemic and material plateauing, there is a third category referred to as life plateauing. They describe life-platforming as an employee's feeling that he or she is lost or stuck in his or her positions outside of work.

Although career plateauing has been related to both positive and negative organizational outcomes, researchers such as Lee (2003) and Tremblay and Roger (1993) have shown that plateauing has more negative outcomes. For example, hierarchical plateauing is correlated with absenteeism among workers, low levels of satisfaction with managers, increased health issues, high levels of work-related stress and burnout, and high turnover intentions (Tremblay et al., 1995). Hierarchical plateauing has resulted in low levels of work satisfaction, lack of organizational engagement and weak job performance (Chao, 1990; Milliman, 1992; Allen et al., 1999). In a study conducted in Pune, India, by Penkar and Agrawal (2012) to investigate career plateauing in the education sector, it was identified that career plateauing among teachers occurred when their jobs became routine and boring tasks or when desired promotions were not forthcoming. These teachers were likely to feel a sense of loss and became pessimistic about the pursuit of satisfaction in their careers.

In Kenya, Kabeti (2011) examined the profession of secondary school teachers in the district of Imenti South. The study found that about $87 \%$ of teachers had worked in the same job category for up to 10 years. This led to career plateauing of teachers with negative effects such as work stress, less job satisfaction, and low job results. This study by Kabeti (2011) used the promotion as the only predictor of the career of teachers. Therefore, the analysis only dealt with systemic plateauing, without dwelling on work quality plateauing. The goal of this paper 
Journal of Educational Research in Developing Areas (JEREDA)

Vol. 2. Issue 2, Pp. 196-207, 2021

http://www.jeredajournal.com

E-mail: info@jeredajournal.com

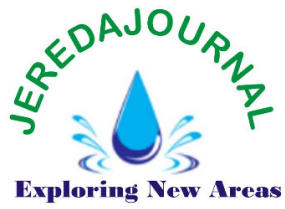

was to review studies on the types of career plateauing (structural or work content) faced by teachers in public secondary schools in Kenya. It also explores the relationship between career plateauing and turnover intentions, the relationship between turnover intentions and teacher preparation, the history characteristics of career plateauing and turnover, and strategies for enriching the work quality of teachers to fight career Plateau.

\section{CONCEPTUAL FRAMEWORK}

The review aimed to demonstrate how career plateauing affects teacher turnover and their decision to undertake further studies. The Career Plateau represents teachers' feelings for growth and development. This development can be both extrinsic and inherent through promotion and demanding work. It is also fair to assume that there is correlation between career channels, attrition intentions and decisions to enroll in

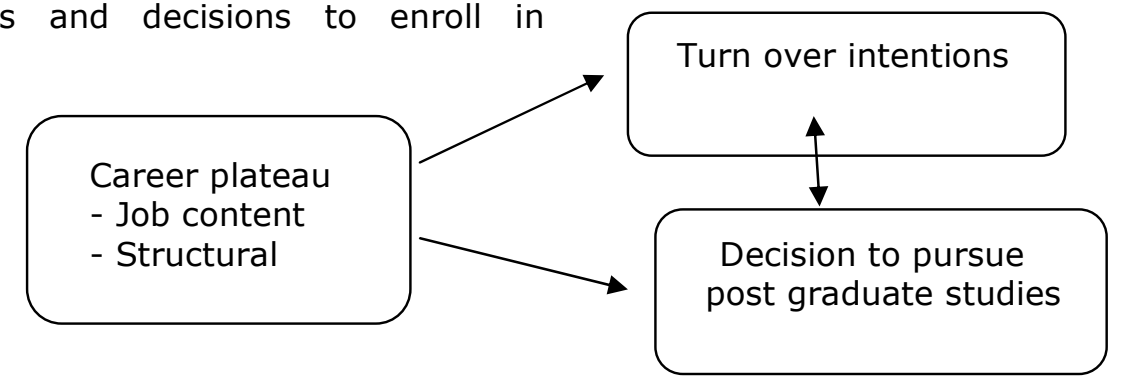

Figure 1: Relationships among career plateauing, turnover intentions and secondary school teachers' pursuit of post-graduate studies

Job content plateauing happens when teachers feel that their work and duties are not demanding. On the other hand, teachers approach systemic (or hierarchical) plateauing when they believe they have limited more vertical movement, i.e. advancement within the organization. The study argues that, like workers in every other field, teachers equate their advancement in the teaching profession to the level of aspiration that they see as a reference point that is psychologically neutral and acts as a benchmark between career success and failure. As a result, teachers experience career growth when they feel that the teaching profession does not have the requisite conditions (either work material further studies. As teachers hit career plateaus, they improve their human capital stock through structured education (post-graduate courses) and on-the-job training. According to Kirby \& Grissmer (1993), investment in human capital training may be either general or unique. General training is the type of training that can be easily applied to other occupations for the purpose of earning more or for other benefits. Relevant training, on the other hand, can create an organization-specific human capital and is a training that is specific to a school in which a teacher operates or another school. The purpose of the paper was to explore the relationship between career trapping, turnover intentions and the decision of the teacher to undertake further studies. Career plateauing, as seen in Figure 1, may be either in the form of work material or structural plateauing.

or structural) to fulfill their career aspirations. The study further suggests that as teachers experience career plateauing, they perform increased searches and are more likely to undertake risk-enhancing acts in an attempt to improve the factors that trigger plateauing. One such riskenhancing behavior is to participate in postgraduate studies, which is well known in the risk-return trade-off of human capital investment (Christiansen, Joensen \& Nielsen, 2006). Depending on the type of training experience, teachers can choose to enroll in postgraduate courses related to education (e.g. education administration, guidance and counseling or master's degrees in their 
Journal of Educational Research in Developing Areas (JEREDA)

Vol. 2. Issue 2, Pp. 196-207, 2021

http://www.jeredajournal.com

E-mail: info@jeredajournal.com

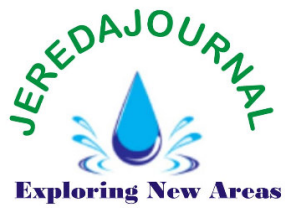

teaching subjects) or non-educational courses (e.g. business administration, gender and development studies, human resource management, etc.).

The study is focused on the premise that teachers experiencing a systemic stagnation, by sensing decreasing prospects for hierarchical development, opt to enroll in educationrelated courses that will increase their chances of promotion. On the other hand, teachers with a job content plateau would feel overwhelmed by the repetitive existence of the teaching career and the lack of demanding work tasks. Such teachers can enroll in non-educational postgraduate courses with a view to leaving the teaching profession. Therefore, the intention of turnover is projected to be higher for teachers experiencing plateauing in work content.

\section{REVIEWS ON STUDIES OF RELATIONSHIP BETWEEN CAREER PLATEAUING AND TURNOVER INTENTIONS}

An organization whose employees are depressed by job plateauing is likely to have major adverse effects, with employees having a strong propensity to leave the organization. Foster, Shastri and Withane (2004) published a review of the employee mentoring program on job grading and employee turnover intentions. The research, which used Canadian Certified Management Accountants as subjects showed that career stagnation was associated with the intentions of turnover. The study also found that the staff who participated in mentoring programs had substantially lower plateau trends and attrition intentions compared to their colleagues who did not participate in such programs. Salami (2010) carried out a study among Nigerian employees to find out if there is a relationship between career forum, employee engagement, turnover intentions and job satisfaction. The research also tried to evaluate the moderating function of mentoring these relationships. The Salami analysis used data from 280 Nigerian civil servants. The results of the study showed that the employee career platform had a negative

association with organizational engagement and work satisfaction. Furthermore, it has shown that career plateauing has a positive relationship with the intentions of turnover.

In another report, Heilmann, Holt and Rilovick (2008) explored the influence of career plateauing on turnover. In this research, Heilmann et al. (2008) analyzed data from 223 workers with the goal of testing the hypothesis that career plateauing has a positive relationship with the intentions of turnover. Their studies have shown that career plateauing is positively associated with the intentions of turnover. The study also found that career plateauing affects turnover intentions differently than career engagement and job satisfaction because career plateauing explicitly influences intentions rather than being mediated by job search behaviors. Lee (2003) performed a study to assess how the professional network would improve the clarification of employees' job outcomes. The Professional Plateau is a place where the work is not a challenge and where there are few opportunities for workers to improve professional growth and potential jobs. The focus group for the study consisted of 300 contacts in 20 engineering companies in Singapore specializing in electrical, civil, electronic or mechanical engineering. Data was obtained by the use of questionnaires. One of the hypotheses of this research was that the professional plateau would account for a substantial variation in three work outcomes - namely career satisfaction, job satisfaction and turnover intentions. The findings revealed that the professional plateau had a very large difference in the three job results. The study sought to find out if in the Kenyan context, there is a connection between career plateauing and turnover intentions among public secondary school teachers.

REVIEW OF STUDIES ON THE RELATIONSHIP BETWEEN TURNOVER INTENTIONS AND DECISIONS TO PURSUE FURTHER STUDIES

Studies in teaching professions (Thomas, 2007; Ingersoll, 2003; 
Journal of Educational Research in Developing Areas (JEREDA)

Vol. 2. Issue 2, Pp. 196-207, 2021

http://www.jeredajournal.com

E-mail: info@jeredajournal.com

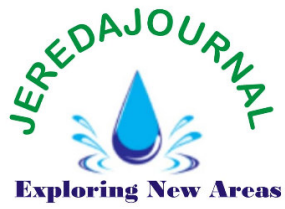

Luekens, Lyter, Fox, \& Chandler, 2004) have shown that turnover is a multifaceted concept. Teacher turnover has been classified into various categories, each influencing human capital and social capital in a different way (Thomas, 2007). Several teachers have left teaching to entered organizations in other fields. Others move to other schools but still serve as teachers (Ingersoll, 2003; Luekens, Lyter, Fox, \& Chandler, 2004). Other teachers quit teaching for a while and then enter the profession later (Murnane, Singer, Willett, Kemple et al., 1991). Other teachers quit teaching for various jobs but in the field of education (Anderson \& Olsen, 2005), for example, to serve as quality assurance and standards officers and education officers. Human capital rises are linked to the first form of attrition - through which teachers opt for more lucrative employment in other fields outside the education sector (Thomas, 2007).

On the other hand, social capital is often related to the second form of turnover - through which teachers change jobs in the field of education in an attempt to improve mobility. Individuals with qualifications, expertise and information that could be appealing to non-educational fields typically leave the sector for financial incentives. These individuals are said to have a high degree of human capital. Other people may have connections and influence that will help them progress in their careers. These teachers have high levels of social capital. Non-monetary incentives, such as support from fellow teachers and school administrators, are often seen by teachers as an important aspect to consider when making career choices. Other considerations include, but are not limited to, demanding job tasks, opportunities for advancement, standards of school facilities, available resources, engagement in the decision-making process, behavior of learners and assigned teaching hours. These working conditions would depend on the type of school in which the school is situated and the demographics of pupils, parents and teachers.

Human capital can be improved by in-service preparation, progression in education through formal education, induction courses or any other program intended for professional growth and development. According to Kirby \&Grissmer, 1993) training where one acquires skills that can be applied to other professionals for the purpose of salary enhancement and other benefits is referred to as general training. In the other hand, specialized training is primarily for the creation of a company's human capital, such as teacher training for the purpose of its function in a specific school. It is a training unique to a school in which a teacher operates or to some other school (Kirby \&Grissmer, 1993). In this review, it would be important to find out the motivating factors behind the choice of teachers to take post-graduate courses.

A number of studies have been conducted on the correlation between the level of education attained and the intentions of turnover. In Bloland and Selby's (1980) analysis of the literature on teacher turnover, educational attainment contributed little to teacher mobility. Their results were partly compatible with the study by Marso and Pigge (1995), which showed that the relationship between the level of education and attrition, whether a teacher completed a two-year teaching college or earned a bachelor's degree, was unrelated to continuing education. Teachers who completed graduate work or earned a master's degree, however, tended to teach longer than other teachers. This finding indicates that the extent of vocational training in education gives rise to a greater dedication to teaching, resulting in a larger proportion of continuing work.

Thomas (2007) noted that some teachers quit their full-time classroom teaching positions in the diversifying field of education for other work in the field. He argued that these teachers, who are part of the "teacher attrition epidemic," have a "investment goods" orientation towards their professions (Thomas, 2007, p. 19). He also noted that such an orientation potentially requires mobilizing 
Journal of Educational Research in Developing Areas (JEREDA)

Vol. 2. Issue 2, Pp. 196-207, 2021

http://www.jeredajournal.com

E-mail: info@jeredajournal.com

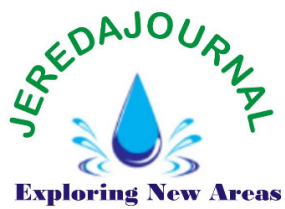

heterogeneous social capital to take higher status" positions. In his study of the social networks of 99 urban educators, Thomas found that positionchangers (those who had switched from full-time teaching to other roles in the field of education) had more heterogeneous ego networks than retained teachers in terms of age, profession, social function and relative communication status. Logistic regression has shown that heterogeneous social capital and longevity education - both manifestations of investment goods job orientation - have had major positive effects on shifting roles. These findings indicate that a predictable degree of achievement activity may account for a significant theportion of attrition of highly qualified teachers. The study decided whether the intentions of turnover are related to the decision of teachers to undertake post-graduate studies.

Dixon and Ward (2015) explored the reasons why teachers are completing master's degrees and the type of job support provided during enrolment. The research involving 18 practicing teachers, found that the reasons for pursuing academic studies were very closely related to their understanding of what it means to be a teacher and how to improve teaching and learning. Dixon and Ward (2015) indicated that the professional identity of teachers seemed to represent the discourse of teaching as a dynamic and professional practice. Such an identity appeared to contradict that of many of their co-workers and senior managers who provided the teachers with subtle signals about the significance and value of study and analysis for the professional practice of teachers.

Williams (2005) carried out a qualitative review of six experienced teachers in New Zealand with the goal of defining the role of academic research in the professional development of teachers. The study found that the key factors contributing to teacher learning included: opening their minds to new perspectives; the need to examine and synthesize ideas, information and concepts as part of the in-class

discussion and evaluation tasks; the value of theory; and the role of reflection and collaboration with others. Williams (2005) argued that postgraduate studies have the ability to bring real improvements to the thought and practice of teachers and thus make a crucial contribution to their professional learning.

Harvey (2005) conducted a study of motivating factors affecting the involvement of teachers in postgraduate studies. Participants in the study $(N=178)$ included primary and secondary teachers in five Christian schools located in the south-eastern region of Queensland, Australia. The study described the strongest motivators for postgraduate teachers as the desire to gain expertise and skills in particular subject areas (pedagogical content); the desire to serve their students more meaningfully and help their students learn better (serving and enabling students); and the ability to explore the principles and values underlying educational issues and the traineeship. The studies reviewed above seem to indicate that all teachers undertaking post-graduate studies are doing so with a view to be better teachers. Studies may not indicate whether there are teachers whose intention to undertake further studies is to obtain jobs in other sectors outside ofthe teaching profession. This research, as one of the goals, aimed to find out if there were teachers who, as a result of the experience of career graduation, enrolled in further studies with a view to leaving the teaching profession.

\section{REVIEW ON STUDIES OF BACKGROUND CHARACTERISTICS ASSOCIATED WITH CAREER PLATEAUING AND TURNOVER}

Studies that looked at some of the causes of career plateau focused on a three-factor causal model (Tremblay \& Roger, 1993). The model suggests that what defines the hierarchical plateau can be related to three variables, namely the family, the individual, and the organization. Person considerations include age, tenure, control area, level of 
Journal of Educational Research in Developing Areas (JEREDA)

Vol. 2. Issue 2, Pp. 196-207, 2021

http://www.jeredajournal.com

E-mail: info@jeredajournal.com

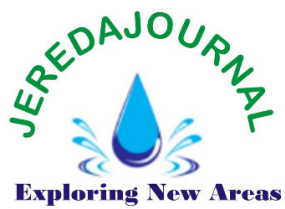

education, skills or lack of skills and individual aspirations. Family considerations include whether one is happy with the family, the family size, the family pressure and the occupation of the spouse. Organizational considerations include career direction and structural characteristics (staff or line position). Tremblay and Roger have empirically validated the three-factor causal model (Tremblay \& Roger, 1993). In a study designed to identify the causes and effects of the career plateau in China, Baoguo and Mian (2008) found that the career plateau is not determined or affected by gender, age, educational level or seniority in the organization, but the career plateau has a major impact on work tenure and career direction. This is consistent with the three-factor causal model of Tremblay \& Roger (1993).

Palmero, Roger and Tremblay (2001) carried out a job satisfaction and part-time career network analysis. The study was carried out among 155 employees of 12 companies in the south of France. Multiple regression analysis found that context variables (gender, educational level, and having a young child) contributed 5.9 per cent of the variance in the career plateau. In their literature review, Ongori and Agolla (2009) cite researchers (Yamamoto, 2006; Applebaum and Santiago (1997) whose work has shown that some of the factors that could contribute to career plateau are those who hold positions of responsibility longer, mergers and takeovers in companies that cause layoffs, which result in fewer positions available but are competitive. Ongori and Agolla (2009) further note that career plateau is observed where rivalry and age factors and organizational needs exist. Competition may be brought on by the fact that in a given position, certain people could be perceived as less qualified than others, and some of the qualified people are actually outside the organisation. The organization may consider elderly people to be undesirable in the organization, choosing instead to offer opportunities to younger candidates (Ongori \& Agolla, 2009).

In a study comparing male and female managers in their career development, Stroh, Brett and Reilly (1992) found that there was no substantial difference in the rate at which male and female managers were promoted. They noticed that there was a gap in wage growth and regional mobility where female managers lagged behind. The goal of this study was to decide if there are substantial differences in career graduation, turnover intentions and the decision of teachers to undertake different post-graduate courses across gender, age and academic qualifications. The analysis also tried to decide whether the situation in Murang'a and Nyandarua is the same or different, and also to evaluate the effects of the rural - urban divide.

Mulei, Waita, Mueni, Mutune and Kalai (2016) investigated the factors affecting the attrition of teachers in public secondary schools in Mbooni-East Sub-County, Kenya. The survey used the questionnaire to collect data from 202 respondents, including one Sub-County Director of Education, one Sub-County Officer of Human Resources, 29 Principals and 171 Teachers. Among the results of the survey, there were more male (62 per cent) than female (38 per cent) teachers who had left teaching in the Sub-County. This, according to Mulei et al. (2016), could be due to the majority of male teachers employed in Mbooni East, male teachers were searching for an escape at a higher rate, and male teachers were experiencing professional misconduct at a rate that was disturbing, as all teachers affected by prohibitions and dismissals were male. Another finding of the study was that $10 \%$ of teachers attrition were teachers who pursued postgraduate studies (Masters and $\mathrm{PhD}$ ), indicating that the quality of education of teachers was a factor that affected the attrition of teachers in the Mbooni East District (Mulei et al., 2016). Locklear (2010) undertook an analysis of the factors leading to the retention of teachers in Georgia. The study used a mixed-method research design with a sample size of 545 teachers from both northern and southern 
Journal of Educational Research in Developing Areas (JEREDA)

Vol. 2. Issue 2, Pp. 196-207, 2021

http://www.jeredajournal.com

E-mail: info@jeredajournal.com

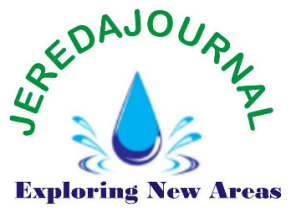

counties of the state of Georgia, USA. The study found that the majority of teachers in the state of Georgia had earned their master's degree, were trained within the first 5 years of their employment, and regarded administrative support and working conditions as positive aspects of their careers. This research by Locklear (2010) found that gender and study year were not predictors of teacher turnover. Similarly, a study conducted by Salahudin, Abdullah and Hitam (2007) assessed the relationship between personal characteristics, occupational stress and intentions of turnover among school teachers in Negeri Sembilan, Malaysia. This study showed that there were no statistically substantial variations in the overall intention of the respondents to change when grouped by gender.

Guarino, Santibáñez and Daley (2006) conducted a critical analysis of the empiric literature on recruitment and retention of teachers published in the United States. The goal of the study was to analyze the characteristics of teachers joining and remaining in the teaching profession, the characteristics of schools and districts that effectively attract and retain teachers, and the types of policies that demonstrate evidence of effectiveness in recruiting and retaining teachers. A common trend that emerged from the updated empiric works is that the turnover was high for young or inexperienced teachers and lower for older or more experienced teachers before they entered retirement ages (Guarino, et al., 2006). Similar results were obtained from Ingersoll and Merrill (2010), whose research included an overview of 20 years of demographic data from the School and Staffing Survey in the United States.

These results may be due to a rise in the satisfaction of teachers with years of teaching experience (Liu \& Ramsey, 2008; Menon \& Athanasoula-Reppa, 2011). Liu and Ramsey (2008), in an analysis of teacher satisfaction with various aspects of their work through multi-level analyzes of national surveys conducted in the United States, found

that job satisfaction among teachers varied with years of teaching. The job satisfaction of teachers improved as years of teaching experience increased. Similar findings were obtained by Menon and Athanasoula-Reppa (2011), whose research was conducted in Cyprus to examine the relationship between gender and teaching experience and work satisfaction in secondary education. This could explain why teachers with less teaching experience are more likely to leave their teaching experience behind. The studies reviewed in this section include inconclusive findings on the role of gender and age in career graduation, the intentions of turnover and the pursuit of postgraduate studies among teachers. The current study aimed to find out if there are substantial gaps in career graduation, turnover intentions and the decision of teachers to undertake different post-graduate courses: gender, age and teaching experience.

\section{CONCLUSION}

Job material plateauing was an indicator of the intentions of teachers to make a turnover. Turnover intentions increased as teachers encountered a plateau of work material. Both institutional plateauing and work content career plateauing were important predictors of the decision of teachers to undertake post-graduate studies. If teachers have encountered systemic, work content or both forms of plateau, they are likely to respond by enrolling in post-graduate studies as one way to resolve plateauing. Studies have shown that there has been a positive relationship in structural plateauing over age, and the teaching experience of teachers has shown that both old and long-standing teachers have a high degree of structural plateauing (Gaturu \& Njuguna, 2020).

Studies have also shown that there has been a substantial gap in turnover intentions across age and in the teaching experience of teachers. Older teachers and those with a high degree of teaching experience have lower attrition intentions than young and less experienced teachers. The gender and 
Journal of Educational Research in Developing Areas (JEREDA)

Vol. 2. Issue 2, Pp. 196-207, 2021

http://www.jeredajournal.com

E-mail: info@jeredajournal.com

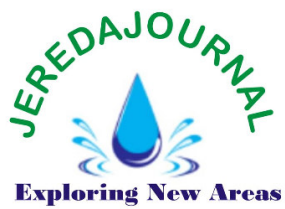

teaching experience of the teachers had a major effect on the participation of the teachers in post-graduate courses. More males pursue post-graduate studies than females, and higher-level teachers have been reported as having pursued or considering post-graduate studies. The paper analyzed research that aimed to demonstrate how career-platforming affects the turnover of teachers and their decision to undertake post-graduate studies. The Career Plateau represents the teachers' feelings for growth and development. This development can be both extrinsic and inherent through promotion and demanding work. It is also fair to assume that there is correlation between career channels, attrition intentions and decisions to enroll in postgraduate studies. As teachers hit career plateaus, they improve their human capital stock through structured education (post-graduate courses) and on-the-job training.

Conflicts of Interest: The authors declare no conflict of interest.

\section{Notes on Authors}

Mary Gaturu now works in a national office in Kenya with the Ministry of Education as the Director of Quality Assurance and Standards. At the time of her study, she was the Director of Education at Muranga County Level as well a Quality Assurance officer earlier. Her interests are gender, education and is highly experienced in matters of education admistration.

Felicita Wanjiru Njuguna is a senior lecturer in Educational Management and Policy at Kenyatta University. Her research interests are in gender, policy and management of education. She is the chair of Muranga County Education Board and Chair of Women Educational Researchers of Kenya, also a member of ANIE- African Network of Internationalisation of Education among others.

Rufus Olanrewaju Adebisi is a graduate of Federal College of Education (Special) Oyo and Department of Special Education and Rehabilitation Sciences, University of Jos, Jos, Plateau State,

Nigeria, where he bagged Nigeria Certificate in Education (NCE) and Bachelor in Education (BEd), Master in Education (MEd), Doctor of Philosophy (PhD) in Special Education respectively. $\mathrm{He}$ is currently teaching at his AlmaMata, in the Department of Education for Learners with Communication and Behaviour Disorders, Federal College of Education (Special) Oyo, Oyo State, Nigeria. His research interests are in Learning Disabilities, Autism Spectrum Disorders, Attention Deficit Hyperactivity Disorders and trace elements/micronutrients in managing disabilities. $\mathrm{He}$ is a researcher, manuscript Reviewer, Editor and Managing Editor, currently serving as member of Editorial Boards in many national and international Journals. He has attended conferences and published several articles in National and International Journals.

Authorship and Level of Contribution: The first author searched the literature, wrote and compiled the manuscript, while the second and third authors brought the materials consulted together, reviewed it. Moreover, all the authors participated in the review of the paper.

\section{Disclaimer Statement}

The review article has been developed from the Thesis in which one of the author was awarded Doctor of philosophy degree. The title of the thesis which was presented to Department of Education Management, Policy and Curriculum Studies in Kenyatta University, Kenya.

\section{REFERENCES}

Allen, T. D., Russell, J. E. A., Poteet, M. L. \& Dobbins, G. H. (1999). Learning and development factors related to perceptions of job content and hierarchical plateauing. Journal of Organizational Behaviour, 20(7), 1113.

Anderson, L.,\& Olsen, B. (2005).Studying the career pathways of urban teachers in Los Angeles. 
Journal of Educational Research in Developing Areas (JEREDA)

Vol. 2. Issue 2, Pp. 196-207, 2021

http://www.jeredajournal.com

E-mail: info@jeredajournal.com

Appelbaum, S.H.,\& Santiago, V. (1997).Career development in the potential organizations. Career Development International, 2(1), 11-20703.

Atteberry, A., Loeb, S.,\& Wyckoff, J. (2013). Do first impressions matter? Improvement in early career teacher effectiveness. Working Paper No. 90. http://auth.calder.commonspotclou d.com/publications/upload/wp90.p $\underline{\mathrm{df}}$

Baoguo, X.,\&Mian, X. (2015). Anempirical research on causes and effects of career plateau. Proceedings of the 7th International Conference on Innovation \& Management, P. 1730.

Bardwick, J. M. (1986). The plateauing trap. American Management Association.

Bloland, P.A.,\& Selby, T.J. (1980). Factors associated with career change among secondary school teachers: A review of the literature. Educational Research Quarterly, 5(3), 13-24.

Burke R.J.,\&Mikkelsen, A. (2006). Examining the career plateau among police officers. International Journal of Police Strategies and Management, 29 (4), 691-703.

Chao, G. T. (1990). Exploration of the conceptualization and measurement of career plateau: A comparative analysis. Journal of Management, 16(1), 181-193.

Choudhary, S. A., Ramzan, M.,\&Riaz, A. (2013). Strategies for career plateau: Empirical investigation of organizations in Pakistan. Interdisciplinary Journal of Contemporary Research in Business, 4(9), 712-726.

Cotton, J.,\& Tuttle, J. (1986). Employee turnover: A meta-analysis and review with implications for research. Academy of Management Review, 11, 55-70.

Dixon, H.,\& Ward, G. (2015). The value of masters' study to teachers' professional practice: Contradictory discourses within the workplace.

Australian Journal of Teacher Education, 40(2), 52-65.

Gaturu, M., \&Njuguna, F. W. (2020). Career plateauing and its relationship with secondary school teachers' pursuit of post-graduate studies in Nyandarua and Murang'a counties, Kenya. Journal of Educational Research in Developing Areas, 1 (2), 153-166. https://doi.org/10.47434/JEREDA/ 1.2.2020.153.

Guarino, C. M., Santibañez, L. \& Daley, G. A. (2006). Teacher recruitment and retention: A review of the recent empirical literature. Review of Educational Research, 76 (2), 173-208.

Harvey, P. (2005). Motivating factors influencing teachers' engagement in postgraduate study: The results of a study of five schools. A paper presented at the Australian Association for Research in Education Conference 2005.

Heilmann, S. G., Holt D. T.,\&Rilovick, C. Y. (2008). Effects of career plateauing on turnover: A test of a model. Journal of Leadership \& Organizational Studies, 15(1), 5968.

Ingersoll, R.,\& Merrill, L. (2010). Who's teaching our children? Educational Leadership, 67 (8), 14-20.

Ingersoll, R. (2003). Is there really a teacher shortage? CPRE Research reports.

http://repository.upenn.edu/cpre $r$ esearchreports $/ 37$

Kabeti, J. J. (2014).Strategies of managing career plateau among secondary school teachers. Thesis; Imenti South, Kenya.

Kirby, S.,\&Grissmer, D. W. (1993). Teacher attrition: Theories, evidence, and suggested policy options. RAND Corporation. (ERIC Document Reproduction Service No. ED 364533).

Lee, P. C. B. (2003). Going beyond career plateau: Using professional plateau to account for work outcomes. Journal of Management Development, 22(6), 538-551. 
Journal of Educational Research in Developing Areas (JEREDA)

Vol. 2. Issue 2, Pp. 196-207, 2021

http://www.jeredajournal.com

E-mail: info@jeredajournal.com

Liu, X. S.,\& Ramsey, J. (2008). Teachers' job satisfaction: Analyses of the teacher follow-up survey in the United States for 2000-2001. Teaching and Teacher Education, $24(5), 1173-1184$.

Locklear, T. M. (2010). Factors contributing to teacher retention in Georgia. Unpublished PhD Dissertation, The University of Alabama.

http://acumen.lib.ua.edu/content/ u0015/0000001/0000298/u0015 0 $0000010000298 . p d f$

Luekens, M. T., Lyter, D. M., \& Fox, E. E. (2004). Teacher attrition and mobility, results from the teacher follow-up survey, 2000-01 (NCES 2004-301). National Center for Education Statistics.

Marso, R., \&Pigge, F. (1995). Characteristics associated with teacher attrition: Pre- and postpreparation teaching concerns of candidates teaching or not teaching five years after graduation. Paper presented at the Annual Meeting of the Midwestern Educational Research Association held at Chicago, Illinois.

Menon, M. E.,\&Athanasoula-Reppa, A. (2011). Job satisfaction among secondary school teachers: The role of gender and experience. School Leadership \& Management, 31 (5), 435-450.

Milliman, J.F. (1992). Causes, consequences, and moderating factors of career plateauing. Unpublished PhD Thesis, University of Southern California. http://digitallibrary.usc.edu/cdm/re f/collection/p15799coll3/id/271573

Mulei, K. O., Waita, K. J., Mueni, K. B., Mutune, M. J. \&Kalai, J. (2016). Factors influencing teacher attrition in public secondary schools in Mbooni-East sub-County, Kenya.International Journal of Education and Research, 4(3), 367-382.

Murnane, R. J., Sincer, J. D., \& Willett, J. B. (1988). The career paths of teachers: Implications for teacher supply and methodological lessons

for research. Educational Researcher, 7, 22-30.

Ongori, H. \&Agolla, J. E. (2009). Paradigm shift in managing career plateau in organisation: The best strategy to minimize employee intention to quit. African Journal of Business Management, 3 (6), 268271.

Palmero, S., Roger, A.,\& Tremblay, M. (2001). Work satisfaction and career plateau of part-time workers. Paper presented at the GOS 17th Colloquium Lyon, 2001, Sub Theme 14 (Career as Professional Odyssey).

http://centremagellan.univIyon3.fr/fr/articles/88 567.pdf.

Penkar, D. J.,\& Agrawal, K. (2012): A study of career plateau in education sector. International Journal of Business and Management Tomorrow, 2(3), 1-17

Rotondo, D. M.,\&Perrewe, P. L. (2000).Coping with a career Plateau: An empirical examination of what works and what doesn't. Journal of Applied Social Psychology, 30, 2622-2646.

Salahudin, S. N., Abdullah, M. M.,\&Hitam, S. (2007). Personal characteristics, occupational stress and turnover intentions among school teachers in Negeri Sembilan, Malaysia. http://repo.uum.edu.my/1714/1/P ERSONAL_CHARACTERISTICS,_OC CUPATIONAL_STRESS.pdf

Salami, S. O. (2010). Career plateauing and work attitudes: Moderating effects of mentoring with Nigerian employees. Journal of International Social Research, 3(11), 499-508.

Sharti T.,\&Withane, S. (2004).The impact of mentoring on career plateau and turnover intentions of management accountants. Journal of Applied Business Research, 20(4), 33-43.

Stroh, L. K., Brett, J. M., \& Reilly, A.H. (1992). A comparison of female and male managers' progression. Journal of Applied Psychology, 77, 251-260.

Thomas, A. (2007). Teacher attrition, social capital, and career 
Journal of Educational Research in Developing Areas (JEREDA)

Vol. 2. Issue 2, Pp. 196-207, 2021

http://www.jeredajournal.com

E-mail: info@jeredajournal.com

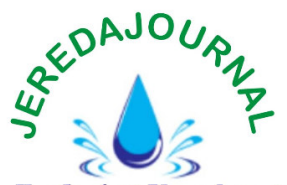

Exploring New Areas

advancement: An unwelcome message. Research and Practice in Social Sciences, 3(1), 19-47.

Tremblay, M.,\& Roger, A. (1993). Individual, familial and organizational determinants of career plateau: An empirical study of the determinants of objective and subjective career plateau in a population of Canadian managers. Group \& Organization Management, 18(4), 411-425.

Williams, R. (2005). The role of academic study in teachers' professional development.Journal of In-service Education, 31(3), 455-470. 